\title{
Diastereoselective Formation of Tertiary Stereocenters via Mizoroki-Heck Reaction
}

\author{
Ane R. Azcargorta, ${ }^{1}$ Esther Lete, ${ }^{1}$ and Nuria Sotomayor ${ }^{1 *}$ \\ 1 Departamento de Química Orgánica II, Facultad de Ciencia y Tecnología, Universidad del País \\ Vasco / Euskal Herriko Unibertsitatea UPV/EHU. Apdo. 644. 48080 Bilbao, Spain. \\ http://www.ehu.es/oms \\ * Author to whom correspondence should be addressed; E-Mail: nuria.sotomayor@ehu.eus; \\ Tel.: +34 946015389; Fax: +34 946012748.
}

\section{Published: 4 December 2015}

\begin{abstract}
The diastereoselective Mizoroki-Heck reaction of $N$-benzylpyrrolidines that incorporate a protected allylic alcohol moiety allows the synthesis of enantiomerically pure pyrrolo[1,2-b]isoquinolines, generating a tertiary stereocenter. The best results were obtained with the use of bulky phosphanes, as $\mathrm{P}(o-\mathrm{Tol}) 3$. When a good leaving group, such as pivaloyl is used as a protecting group, the trans-10-vinyl substituted pyrroloisoquinoline (10S,10aS)-2a is obtained as the major diastereoisomer in moderate yield. On the other hand, when the allylic alcohol is protected as a silyl ether, the protected alcohol is retained, obtaining an enol ether, whichafter deprotection and reduction leads to the trans-10-hydroxymethyl substituted pyrrolisoquinoline $(10 S, 10 \mathrm{a} S)-5$, in enantiomerically pure form, with complete diastereoselectivity.
\end{abstract}

Keywords: Palladium; diastereoselective Heck reaction; alkaloids; pyrrolo[1,2- $b$ ]isoquinolines

Mol2Net YouTube channel: http://bit.do/mol2net-tube

\section{Introduction}

The Mizoroki-Heck reaction (M-H), has found wide application in the preparation of complex organic molecules, from simple substrates including heterocycles. ${ }^{1}$ Particularly, the enantioselective intramolecular M-H reaction has emerged as an excellent tool for the construction of polycyclic frameworks. ${ }^{2}$

In connection with our interest our interest in palladium catalyzed reactions ${ }^{3}$ we recently showed that quaternary stereocenters can be 
generated using chiral phosphane ligands as $(R)$ BINAP, through a cascade polyene cyclization. ${ }^{4}$

The pyrrolo[1,2- $b]$ isoquinoline core is also the characteristic structural unit present in numerous biologically active compounds, as the phenanthroindolizidine alkaloids. ${ }^{5}$ In this context, we have shown that the 6-exo carbolithiation of 2-alkenylpyrrolidines takes place with complete diastereoselectivity, allowing the synthesis of enantiomerically pure hexahydropyrrolo[1,2$b$ ]isoquinolines in high yields. ${ }^{6}$ On the other hand, the Mizoroki-Heck reaction of this type of pyrrolidines leads to enantiomerically pure 10alkyidene substituted hexahydropyrrolo[1,2$b$ ]isoquinolines7 Therefore, we decided to investigate further the scope of Mizoroki-Heck intramolecular reaction towards the stereo controlled synthesis of pyrrolo[1,2$b$ ]isoquinolines, generating a tertiary stereocenter, using a diastereoselective approach.

\section{Results and Discussion}

To start studying the generation of a tertiary centre, we selected as substrate an enantiomerically pure $N$-benzylpyrrolidine that incorporates a protected allylic alcohol, as pivalate 1a, which was prepared in enantiomerically pure form from commercially available $N$-Boc L-prolinal. (Scheme 1).



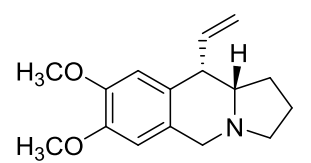

(10S,10aS)-2a

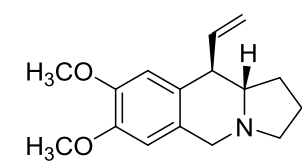

(10R,10aS)-3a

\section{Scheme 1.}

In fact, under classical Mizoroki-Heck conditions $\left[\mathrm{Pd}\left(\mathrm{PPh}_{3}\right)_{4}(10 \mathrm{~mol} \%), \mathrm{NaHCO}_{3}\right.$, $\mathrm{Bu} 4 \mathrm{NCl}, \quad \mathrm{CH}_{3} \mathrm{CN}$, reflux $\left.48 \mathrm{~h}\right]$, pivalate elimination took place, generating a tertiary stereocenter. However, only a low yield (16\%) of a diastereomeric mixture of pyrroloisoquinolines 2a and 3a was obtained, with moderate diastereoselectivity in favor of the trans-isomer 2a (66:34 ratio). After some experimentation, we found that palladium acetate with a bulky phosphane, as tri-ortho-tolylphosphane (Scheme 1, Table 1) was required to obtain moderate to good yields of the diastereomeric mixture of pyrroloisoquinolines 2a and 3a (Table 1). The use of a mixture of $\mathrm{CH}_{3} \mathrm{CN} / \mathrm{H}_{2} \mathrm{O}(10: 1)$ as solvent resulted in reduced reaction times $(72 \mathrm{~h}$ vs $5 \mathrm{~h}$, entry $2 v s$ entry 1), obtaining a comparable yield with no loss of diastereoselectivity. Other phosphanes (entries 37) and bases (entry 8) were also used, but the diastereoselectivity was not improved. Both diastereomers could be separated and characterized. Their stereochemistry was established by NMR and confirmed by X-ray analysis (Figure 1)

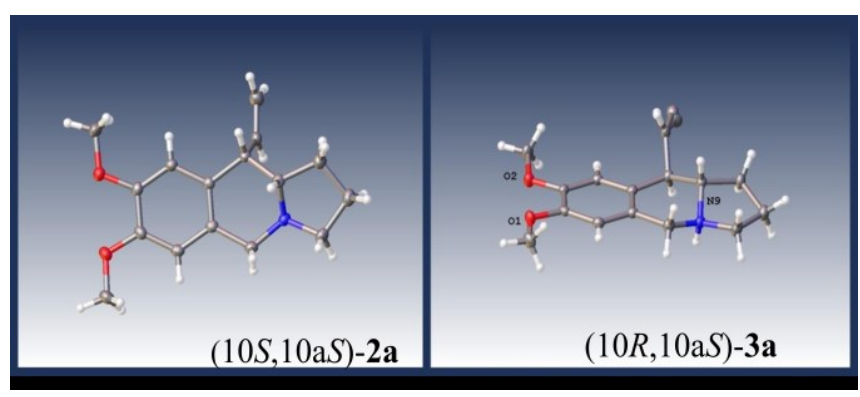

Figure 1. ORTEP plots of compounds $\mathbf{2 a}$ and $\mathbf{3 a}$ 


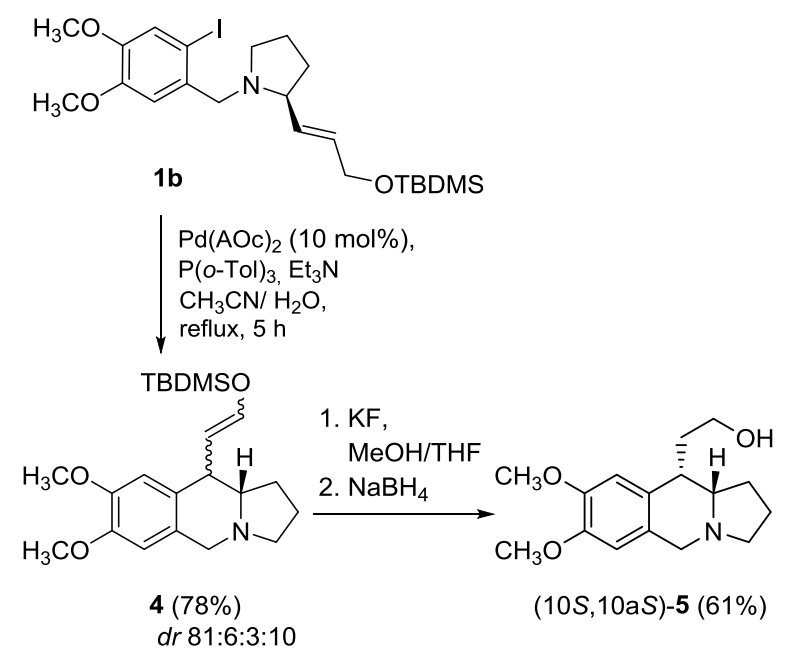

Scheme 2.
Interestingly, when the allylic alcohol is protected with a TBDMS group (1b, Scheme 2), the protected alcohol is retained, generating a tertiary centre and obtaining an enol ether 4 in good yield, as a mixture of diastereomers with the trans major diastereomer as a $E / Z$ mixture. The enol ether could be deprotected and the resulting aldehyde was reduced, to obtain alcohol $\mathbf{5}$ as a single diastereomer, enantiomerically pure.

Table 1. $\operatorname{Pd}(0)$-catalyzed cyclization reactions of $\mathbf{1 a}$.

\begin{tabular}{lllllll}
\hline Entry & Ligand & Base & Solvent & Time (h) & Yield (\%) & $\begin{array}{l}\text { Ratio } \\
\text { 2a/3a }\end{array}$ \\
\hline 1 & $\mathrm{P}(o-\mathrm{Tol})_{3}$ & $\mathrm{Et}_{3} \mathrm{~N}$ & $\mathrm{CH}_{3} \mathrm{CN}$ & 72 & 51 & $83: 17$ \\
2 & $\mathrm{P}(o-\mathrm{Tol})_{3}$ & $\mathrm{Et} \mathrm{t}_{3} \mathrm{~N}$ & $\mathrm{CH}_{3} \mathrm{CN}: \mathrm{H}_{2} \mathrm{O}$ & 5 & 53 & $78: 22$ \\
3 & $\mathrm{P} t \mathrm{Bu}_{3}$ & $\mathrm{Et}_{3} \mathrm{~N}$ & $\mathrm{CH}_{3} \mathrm{CN}: \mathrm{H}_{2} \mathrm{O}$ & 5 & 32 & $78: 22$ \\
4 & $\mathrm{PCy}_{3}$ & $\mathrm{Et}_{3} \mathrm{~N}$ & $\mathrm{CH}_{3} \mathrm{CN}: \mathrm{H}_{2} \mathrm{O}$ & 5 & 45 & $78: 22$ \\
5 & $\mathrm{DavePhos}$ & $\mathrm{Et}_{3} \mathrm{~N}$ & $\mathrm{CH}_{3} \mathrm{CN}: \mathrm{H}_{2} \mathrm{O}$ & 5 & 51 & $76: 24$ \\
6 & $\mathrm{PPh}$ & $\mathrm{Et}_{3} \mathrm{~N}$ & $\mathrm{CH}_{3} \mathrm{CN}: \mathrm{H}_{2} \mathrm{O}$ & 5 & 32 & $66: 34$ \\
7 & $\mathrm{dppp}$ & $\mathrm{Et}_{3} \mathrm{~N}$ & $\mathrm{CH}_{3} \mathrm{CN}: \mathrm{H}_{2} \mathrm{O}$ & 5 & 51 & $50: 50$ \\
8 & $\mathrm{P}(o-\mathrm{Tol})_{3}$ & $\mathrm{BuNMe}_{2}$ & $\mathrm{CH}_{3} \mathrm{CN}: \mathrm{H}_{2} \mathrm{O}$ & 5 & 35 & $72: 28$ \\
9 & $\mathrm{P}(o-\mathrm{Tol})_{3}{ }^{[\mathrm{a}]}$ & $\mathrm{Et}_{3} \mathrm{~N}$ & $\mathrm{CH}_{3} \mathrm{CN}: \mathrm{H}_{2} \mathrm{O}$ & 22 & 46 & $79: 21$ \\
\hline
\end{tabular}

[a] $5 \mathrm{~mol} \%$ of $\mathrm{Pd}(\mathrm{AcO})_{2}$ was used

\section{Conclusions}

Tertiary stereocenterss can be efficiently generated via Mizoroki-Heck reaction using protected allylic alcohol moieties. The $\beta^{\prime}-$ elimination can be controlled by selecting the protecting group (Piv or TBDMS). The best results in terms of yield and diastereoselectivity were obtained by using bulky phosphanes. Thus, trans-10-vinylpyrroloisoquinoline $(10 S, 10 \mathrm{a} S)$-2a and trans-10-hydroxymethylpyrroloisoquinoline $(10 S, 10 \mathrm{a} S)-5$, have been obtained in enantiomerically pure form.

\section{Acknowledgments}

Ministerio de Economía y Competitividad (CTQ2013-41229-P), Gobierno Vasco (IT-623- 
13) and Universidad del País Vasco / Euskal Herriko Unibertsitatea UPV/EHU (UFI11/22, PPM12/03) are gratefully acknowledged for their financial support. We also thank Gobierno Vasco for a grant (A. R. A). Technical and human support provided by Servicios Generales de Investigación SGIker (UPV/EHU, MINECO, GV/EJ, ERDF and ESF) is also acknowledged.

\section{Conflicts of Interest}

The authors declare no conflict of interest.

\section{References and Notes}

1. Oestreich M. Ed, The Mizoroki-Heck reaction, Wiley: Chichester, 2009; b) Larhed, M., Ed., Science of Synthesis - Cross Coupling and Heck-Type Reactions, Vol. 3, Thieme: Stuttgart, 2013.

2. a) Tietze, L. F.; Ila, H; Bell, H. P. Chem. Rev. 2004, 104, 3453-3516. b) McCartney, D.; Guiry, P. J. Chem. Soc. Rev. 2011, 40, 5122-5150.

3. a) Lage, S.; Martínez-Estibalez, U.; Sotomayor, N.; Lete, E. Adv. Synth. Catal. 2009, 351, 24602468; b) Martínez-Estíbalez, U.; García-Calvo, O.; Ortiz-de-Elguea, V.; Sotomayor, N.; Lete E.; Eur. J. Org. Chem. 2013, 3013-3022; c) Coya, E.; Sotomayor, N.; Lete E. Adv. Synth. Catal. 2014, 356, 1853-1865; d) Ortiz-de-Elguea, V.; Sotomayor, N.; Lete, E. Adv. Synth. Catal. 2015, 356, 463-473.

4. Coya, E.; Sotomayor, N.; Lete E. Adv. Synth. Catal. 2015, 357, 3206-3214.

5. For reviews, see: a) Burtoloso, A. C. B.; Bertonha, A. F.; Rosset, I. G. Curr. Top. Med. Chem. 2014, 14, 191-199; b) Chemler, S. R. Curr. Bioact. Comp. 2009, 5, 2-19

6. García-Calvo, O.; Coya, E.; Lage, S.; Coldham, I.; Sotomayor, N.; Lete E. Eur. J. Org. Chem. 2013, 1460-1470.

7. García-Calvo, O.; Sotomayor, N.; Lete E.; Coldham, I. Arkivoc 2011, 57-66.

(C) 2015 by the authors; licensee MDPI, Basel, Switzerland. This article is an open access article distributed under the terms and conditions defined by MDPI AG, the publisher of the Sciforum.net platform. Sciforum papers authors the copyright to their scholarly works. Hence, by submitting a paper to this conference, you retain the copyright, but you grant MDPI AG the non-exclusive and unrevocable license right to publish this paper online on the Sciforum.net platform. This means you can easily submit your paper to any scientific journal at a later stage and transfer the copyright to its publisher (if required by that publisher). (http://sciforum.net/about ). 